\title{
CO-OPERATIVES AS AN AID TO SMALL BUSINESS IN GERMANY
}

\section{Gerhard Weisser* and Bertel Fassnacht}

The problem of competition is the same for small business in West Germany as in all industrial countries with a competitive economy. Small firms feel the weakness of their bargaining power in competition with large firms in many industries and have, therefore, come to concentrate their activity more in fields of specialized production and services. There is, however, a difference in the attempts that have been made to overcome this weakness. These attempts have had some success and have, therefore, set a pattern for a number of other countries, notably in central and northern Europe. In describing them here, we are confining the discussion to manufacturing, handicraft, and trade, since agriculture has special problems in any industrial country.

The traditional stronghold of small enterprise in Germany and its Mittelstand class of proprietors in Germany has been retailing and, with a stronger corporate tradition, handicraft. In these fields, small business has been able to retain considerable importance, even after a decline during the nineteenth century.

Handicraft firms differ from small industrial firms not necessarily in their method of production or in size, but in the kind of training required of the artisan, in conditions of entry into the trade as regulated by law, and in enrollment at the Handwerkskammer-their corporate administration. Such attributes of status cannot, however, conceal the fact that artisans are embedded in a competitive economy, with little protection against its effects. Table one shows that the total number of artisan firms, which had increased from 792,000 in 1939 to 864,000 in 1949 , has fallen back to $75^{2,000}$ by 1955 , which is below the prewar level. At the same time, the number of persons employed in artisan firms has risen considerably, from 2,600,000 in I939 to 3,600,000 in 1955. The trend towards a higher average number of persons employed per shop has been fairly even in the different branches of handicraft, but some groups show a marked variation from the general pattern: in the metalworking trades and in the glass, ceramic, and other trades (photography, musical instrument-makers, etc.), the number of artisan firms has shown an increase; whereas in woodworking and in textiles, clothing, and leather, the number of persons employed has decreased since 1949 -in the case of the latter group, even to a figure below that of r939.

* Dr. rer. pol. I923, University of Tübingen. Professor of Social Policy and Co-operative Studies, University of Cologne. Author, ForM uNd Wesen der Einzelwirtschaften (1949), Produktrverg Eingliederung (1956). Editor, Morphologie der Einzelwirtschaftzichen Gebilde (1947), Archiv Für ÖFFENTLICHE UND FREIGEMEINWIRTSChaFTLICHE UNTERNEHMEN.

† Dipl.-Kaufmann 1956, University of Cologne; British Council Scholar, 1956-57, University of Birmingham. Assistant, Department of Co-operative Studies, University of Colognc. 
TABLE I

Artisan Firms and Their Employment by Industriat Groups, I939-55

\begin{tabular}{r|r|r|r|r|r|r}
\hline \multirow{2}{*}{ Group } & \multicolumn{3}{|c|}{} & \multicolumn{3}{c}{ Persons Employed in Artisan } \\
Work (thousands)
\end{tabular}

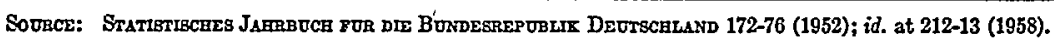

TABLE II

Artisan Firms by Size Groups, I949-56

\begin{tabular}{|c|c|c|c|c|c|}
\hline \multirow{2}{*}{$\begin{array}{l}\text { Size Group (per- } \\
\text { sons employed) }\end{array}$} & \multicolumn{2}{|c|}{ Artisan Firms (thousands) } & \multicolumn{2}{|c|}{ Percentage of Total } & \multirow[t]{2}{*}{$\begin{array}{l}\text { Percentage of } \\
\text { Increase or } \\
\text { Decrease in } \\
\text { Number of } \\
\text { Firms, 1949-56 }\end{array}$} \\
\hline & 1949 & 1956 & 1949 & 1956 & \\
\hline 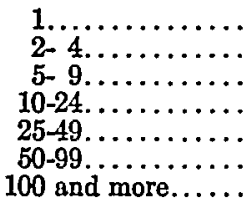 & $\begin{array}{r}315.1 \\
390.2 \\
111.4 \\
36.5 \\
7.0 \\
2.1 \\
0.6\end{array}$ & $\begin{array}{r}249.7 \\
311.4 \\
124.1 \\
47.6 \\
12.1 \\
4.9 \\
1.9\end{array}$ & $\begin{array}{r}36.5 \\
45.2 \\
12.9 \\
4.2 \\
0.8 \\
0.3 \\
0.1\end{array}$ & $\begin{array}{r}33.2 \\
41.5 \\
16.5 \\
6.3 \\
1.6 \\
0.6 \\
0.3\end{array}$ & $\begin{array}{l}-21 \\
-20 \\
+11 \\
+31 \\
+73 \\
+126 \\
+223\end{array}$ \\
\hline Total. & 862.9 & 751.6 & 100 & 100 & -13 \\
\hline
\end{tabular}

Sounce: Kunz-Pfaff, Die GroBenklassen der Handuetksbetriebe nach der Zahl der Beschäftiglen, 6 WIRTSCEArT UND STaTistik 334 (1958).

The vast majority of artisan firms is still very small. Table two shows that in 1956, ninety-one per cent had less than ten persons employed, but that many of these firms headed by craftsmen have grown into larger size groups since I949. The number of firms with less than five persons employed has decreased by one-fifth during this period. Many of these artisans who dropped out had probably entered the trade after the war and were not fully competent. Such an influx into selfemployment occurs usually during postwar years and periods of economic crisis. When economic recovery increases job opportunities, many self-employed prefer the greater stability of a regular pay-check. This readjustment of handicraft has. been brought about by competition from larger artisan firms whose number has grown at the same time. There have been 27,000 of them with more than fifty persons employed in 1949 , but 68,000 in 1956 . Elimination of small units has been 
particularly drastic in the construction and painting trades, where about half of all artisan firms with less than five persons employed closed down during the same period; while in some other trades, notably automobile-repair, and upholstering and decorating, the number of even such small firms has risen considerably. The opportunity of shifting from one branch of handicraft to another, however, is practically nonexistent, on account of very rigid training requirements.

The other field in which small business has traditionally had a very strong position is retailing. Here, competition from large-scale enterprise in the form of chain stores and department stores-even though not as strong as in the United States-has had its effect upon the small independent retailer in recent decades. Consumers' co-operatives, with their price-lowering tendency, have grown again since the war and become another competitor, but have so far concentrated their activity mainly on food distribution. On the whole, however, small independent retailers have proved themselves adaptable to new conditions and have retained their share of the growing market, especially in groceries, where they do about three-quarters of all retail trade.

In the manufacturing industries, the dominant trend of development has been, for a long time, toward larger plants and a concentration of big enterprise. Opportunities for small business in specialized services and in production contracts with large firms have also grown at the same time; these have, however, not been sufficient to allow small firms, on the whole, to attain their proportional share of economic growth. The figures in table three illustrate what has happened from 1953 to 1955

TABLE III

Industrial Establishments (Nonartisan) in Different Size Groups, I953 and 9955

\begin{tabular}{|c|c|c|c|c|c|}
\hline \multirow{2}{*}{$\begin{array}{l}\text { Size Group (num- } \\
\text { ber of employees) }\end{array}$} & \multicolumn{2}{|c|}{ Establishments } & \multicolumn{2}{|c|}{$\begin{array}{l}\text { Sales of Products in Billion } \\
\text { DM during Month of Septem- } \\
\text { ber (DM } 4.20=\$ 1 \text { ) }\end{array}$} & \multirow[t]{2}{*}{$\begin{array}{c}\text { Percentage } \\
\text { Increase of } \\
\text { Sales, 1953-55 }\end{array}$} \\
\hline & 1953 & 1955 & 1953 & 1955 & \\
\hline $\begin{array}{r}1-9 . \ldots \ldots \ldots \\
10-49 \ldots \ldots \ldots \\
50-99 \ldots \ldots \ldots \\
100-199 \ldots \ldots \ldots \\
200-499 \ldots \ldots \ldots \\
500-999 \ldots \ldots \ldots \\
1,000 \text { and more.... }\end{array}$ & $\begin{array}{r}41,619 \\
30,570 \\
8,605 \\
4,980 \\
3,509 \\
1,059 \\
831\end{array}$ & $\begin{array}{r}43,034 \\
30,541 \\
9,163 \\
5,615 \\
3,998 \\
1,259 \\
983\end{array}$ & $\begin{array}{l}0.30 \\
1.24 \\
1.03 \\
1.26 \\
2.22 \\
1.62 \\
4.09\end{array}$ & $\begin{array}{l}0.34 \\
1.42 \\
1.24 \\
1.58 \\
2.78 \\
2.25 \\
5.98\end{array}$ & $\begin{array}{l}13 \\
15 \\
20 \\
25 \\
25 \\
39 \\
48\end{array}$ \\
\hline Total. ..... & 91,173 & 94,034 & 11.76 & 15.59 & 33 \\
\hline
\end{tabular}

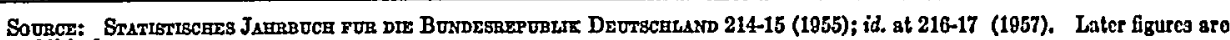
not published.

in a period of over-all growth. Both the number of industrial establishments and the sales of products have increased in almost all size groups, so that the total number of establishments rose to 94,000. While the smaller and medium-sized shops have shown an increase of sales, this increase has, however, considerably lagged behind 
the general average increase of thirty-three per cent. At the same time, the large establishments have increased their sales far above the average rate. There is, in these figures, a clear correlation between size and the rate of increase. Furthermore, it should be noted that these data refer to establishments (local units) only, and not to firms and combinations, so that they do not reveal the full extent of the process of concentration.

In some branches of manufacturing, small business has been able to retain a relatively strong position. These include woodworking, printing, the clothing industry, and dairies, all with an element of service. But the general impression given by these data is that in the manufacturing industry, just as in handicraft production and services, with its traditional prevalence of small workshops, the situation of small business has increasingly become more difficult.

Small enterprise has its definite limitations in relation to large-scale forms of enterprise. Much has been written about the economies of large-scale production, and it is clear that some branches of manufacturing have become quite unsuitable for small units. Small business leaders claim, however, that in the fields where small enterprise exists, it is not in production costs where its main disadvantage lies. They point to evidence of government discrimination against small business in Germany and claim that the tax system works in favor of big business. Under the policy of postwar reconstruction, this has certainly been the case. The sales tax, which constitutes a substantial portion of federal tax income, is levied at each level of transaction, and thus puts a premium on vertical integration of functions. Also, a large part of municipal taxes is raised as a payroll tax from firms and hits small business harder, because its type of specialization has led to a larger proportion of labor costs.

The main structural weakness of small enterprise, regardless of current tax policy and economic fluctuations, is in its market relations. Small firms are unable to obtain the same advantageous rates as larger firms do in their bulk purchases of raw materials. They cannot make use of the same techniques of large-scale marketing and advertising of products. Above all, they have especially serious shortcomings in the increasingly important field of finance. Small firms cannot, to the same extent, utilize market power for the technique of internal financing through the prices charged in a sellers' market. Their access to the capital market is more limited; they cannot offer securities sufficient for long-term bank credit; and where they do obtain credit, they find that the interest rate is higher for small loans than for bigger loans. To supplement their slender equity-capital, they often have to rely on short-term trade credit, which is a very expensive credit and tends to limit their freedom in purchasing. The disadvantages of small scale are equally apparent when a firm wants to ensure itself the services of expert personnel. Often, its size will not warrant the expense for full-time positions, and this factor, as well as the cost of apparatus, has made research for technological development almost exclusively a domain of large enterprise. 
It is, however, a matter of great relevance whether or not an economy has a strong element of small enterprise. If a whole economy is dominated by large firms, controlled perhaps by a small number of influential stockholders, it will lack the greater elasticity and refreshing variety of smaller firms, with their opportunities for independent decision and responsibility. Often the inherent values of the position of self-employment are more highly regarded than the income that goes with it. People may be put to more productive use when employed in a large concern; national output and income may be increased in consequence; but the greater national welfare, with a variety of objects in view, need not at all coincide with maximum national income. When inherent cultural values are in danger of being sacrificed, then the objective of maximizing national income will be disputed. Concentration of economic power and the political influence which may result from it, are recognized to be dangers to cultural values that may lead to public concern and to restrictive government action.

Government action designed to protect the interests of small firms can easily build up a lasting system of privileges and lead to mere conservation of enterprises which would otherwise have adapted themselves to new competitive conditions. Such dependence upon the public can be avoided when preference is given to a policy that develops the competitive ability of small enterprise. It is based not on direct government action, but on the capacity of those concerned to help themselves. Small business can overcome many of its structural weaknesses by self-help, and it has, in Germany, a long tradition of successful co-operative effort to improve its position. Functions for which the individual firm is too small can be fulfilled very effectively by a unit with larger capacity, established by small firms on a co-operative basis. Such a joint enterprise will perform the service for members of the co-operative at the next level and will redistribute any surplus that accrues to these members.

The objective of co-operative enterprise is not to earn a maximum capital dividend for its shareholders, but to perform a service to the membership group. A set of principles has been developed to make this practicable and to safeguard the specific nature of a co-operative association. There shall be democratic control, and each member be given one vote. Interest on capital shall be limited to a fixed rate, and all surplus shall be distributed in proportion to patronage. Part of the surplus will be retained as reserve funds, so that the co-operative can expand its operations. Whether current market prices are charged in the transaction between the members and their co-operative and the surplus distributed later, or a cost price charged in the first place, is, in principle, irrelevant. Members individually withdraw from the market, in fact, when they decide to supply themselves co-operatively. There is a market only in the relations between the co-operative and the outside economy, but at more favorable conditions for participants in the co-operative.

Participating members decide voluntarily whether they avail themselves of the services of their co-operative or not. A co-operative is thus different from a medieval craft guild, where membership was compulsory and the object was not so much to 
establish a joint enterprise, as to regulate the members' market. Likewise, a cooperative is entirely different from a trust, whose object is to dominate and manipulate a market. The object of a co-operative, in contrast, is to increase the efficiency of certain functions of its members, like purchasing, marketing, and obtaining credit or services, by performing these jointly.

The principle and the inherent advantages of large-scale enterprise have, in fact, long been accepted by small businessmen in Germany. They have made use of them through their own co-operative associations. "We cannot do away with big business and we need it," co-operators say, "so we build it it up on our own where it suits us." Large-scale organization based on the ideas of self-help, self-administration, and self-responsibility can compensate small business for its structural disadvantages in market relations, by developing countervailing power.

The practice of co-operative self-help in Germany began in a period of distress in the I840's. The position of small independent craftsmen had become very difficult as a result of increasing competition from emerging industrial enterprise. Some demanded a return to medieval guild regulations by government action. Others advocated a system of relief. The pioneer of co-operative self-help among artisans and other independent people, Hermann Schulze-Delitzsch (1808-83), a district judge in the Prussian province of Saxony and Liberal member of the Prussian Diet, had come to the conclusion that both direct government action and relief work were not in the best interest of these people. He had confidence in their ability to improve their competitive position themselves and began to organize a number of local co-operatives among artisan groups in a few small towns: cabinet-makers' and shoemakers' co-operatives for pooling orders in the purchase of raw materials; credit co-operatives for the pooling of savings, and for supplementing credit needs by a mutual guarantee for bank credits; and marketing co-operatives for the sale of craftsmen's products. At about the same time, another co-operative pioneer, Friedrich Wilhelm Raiffeisen, developed co-operation among rural people in a very similar way. And this was only a few years after a group of weavers in Lancashire, the Rochdale Pioneers, had established their co-operative store in I844 under the previously-mentioned co-operative principles. The important difference was that industrialization in England had progressed further and the Rochdale weavers had become employees. Under the strain of hardship, they set up their co-operative toimprove their position as consumers, while the craftsmen in Germany who organized themselves in co-operatives were still independent producers. The consumers' cooperative movement has since spread from England all over the world, while producers' co-operation had its origin in Germany.

An ultimate objective, both in the attempts of the Rochdale Pioneers and of Schulze-Delitzsch, had been to establish co-operative workshops in industry which would be owned and controlled by the workers on co-operative principles. A number 
of such productive societies have come into operation, but they have frequently failed. ${ }^{1}$ Co-operation has since had its strongest development in those forms where members remain independent and the co-operative assists them in certain functions.

Small business in Germany has thus developed co-operative forms of enterprise in various sectors of its activity to utilize the advantages of large-scale organization. Numerous local co-operatives deal with the provision of raw materials, of credit, or of common services. Some have grown to regional size, and in order to increase their efficiency, all local co-operatives have, in a reapplication of the rationale of their own origin, joined in regional and central federations. These central agencies have been set up along the separate branches of co-operative activity and assist their member co-operatives by such services as wholesaling, importing, auditing, promotion, and consultant services. 'The central conference body of all business groups' cooperatives (for information services and representation in legislative matters) is the Deutsche Genossenschaftsverband (Schulze-Delitzsch), Bonn. Co-operative activity is usually carried out under the legal form of a co-operative association, as defined in the Co-operative Law, which was formulated at first in 1867 as a direct result of the work of Schulze-Delitzsch. But it is in no way confined to this legal form and has, in many cases, adapted other corporate forms for its use.

The most important group of small businessmen's co-operatives are retailers' and artisans' co-operatives for the purchase of goods and raw materials. They assume all functions of a wholesaler, such as storage, transport, risk-taking, and credit, and in addition, assist their members in advertising, market analysis, bookkeeping, and as technical consultants. They have their own co-operative brands, and in some instances, they have proceeded even to production. Table four shows the number

TABLE IV

Purchasing Co-operatives of Business Groups, I957

\begin{tabular}{|c|c|c|}
\hline Group & $\begin{array}{l}\text { Number of } \\
\text { Co-operatives }\end{array}$ & $\begin{array}{l}\text { Annual Sales } \\
\text { (million DM) }\end{array}$ \\
\hline 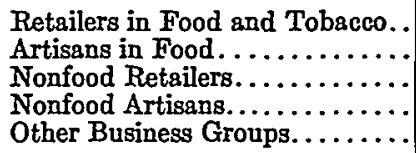 & $\begin{array}{r}396 \\
414 \\
85 \\
247 \\
96\end{array}$ & $\begin{array}{r}2,409 \\
903 \\
1,367 \\
230 \\
750\end{array}$ \\
\hline Total. . & 1,238 & 5,658 \\
\hline
\end{tabular}

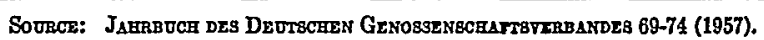

and sales volume of such co-operatives. Of these 1,238 associations, two-thirds are in food distribution-mainly grocers' purchasing co-operatives like those in the

\footnotetext{
1 New proposals to render the administration in this type of enterprise more practicable have been worked out by the Institute of Self-Help, Cologne, with reference also to countries that are now in the process of industrialization.
} 
United States ${ }^{2}$ and independent bakers' and butchers' purchasing co-operatives. These are owned and controlled by the shopkeepers and, therefore, differ from voluntary chains which are organized by private wholesalers. Co-operation among retailers and artisans in other sectors has shown some spectacular developments, but has not spread to the same extent. Other groups with their own purchasing cooperatives include restaurants, hotels, dentists, and private wholesalers.

The value of purchasing co-operatives to their members cannot be represented adequately by their sales volume, because the very existence of such enterprise also has an effect upon the prices and practices of manufacturers and private wholesalers. However, if we compare their scale with that of big business, we find that the aggregate sales of small business purchasing co-operatives in I957 ( $\mathrm{DM}_{5}, 658,000$,000) correspond almost exactly to the aggregate sales of the largest private enterprise in the country, Krupp, and the largest public enterprise, Volkswagen, in the same year (together DM, 5,690,000,000). In this figure are not included the trading federations and the banks for co-operatives with their central credit bank, the Deutsche Genossenchaftskasse, Frankfurt.

The business group with the largest volume of co-operative purchases are grocers. Their 343 co-operative associations are grouped into two separate federations, Edeka with headquarters in Hamburg, and Rewe with headquarters in Cologne, whose services are so comprehensive that these grocers can compete successfully with chain stores. They do about one-third of all food retail business in the country. In spite of attempts to co-ordinate some of their retail marketing, the retailers have not given up any of their entrepreneurial functions. They only delegate them where they choose.

TABLE $V$

Grocers' Purchasing Co-operattves (Edeka and Rewe Organizations), I950-57

\begin{tabular}{c|c|c|c|c}
\hline \hline Year & $\begin{array}{c}\text { Number of } \\
\text { Co-operatives }\end{array}$ & $\begin{array}{c}\text { Number of } \\
\text { Members }\end{array}$ & $\begin{array}{c}\text { Sales of Local } \\
\text { Co-operatives } \\
\text { (million DM) }\end{array}$ & $\begin{array}{c}\text { Sales of Central } \\
\text { Agencies } \\
\text { (million DM) }\end{array}$ \\
\hline $1950 \ldots \ldots \ldots \ldots \ldots$ & 313 & 37,560 & 826 & 455 \\
$1955 \ldots \ldots \ldots \ldots \ldots$ & 328 & 47,600 & 1,749 & 1,113 \\
$1956 \ldots \ldots \ldots \ldots \ldots$ & 327 & 48,390 & 2,004 & 1,335 \\
$1957 \ldots \ldots \ldots \ldots \ldots$ & 343 & 50,400 & 2,216 & 1,489 \\
\hline
\end{tabular}

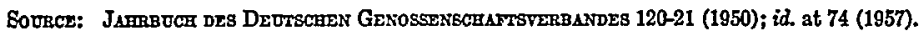

Table five shows the development of these co-operatives since 1950 . Their average membership today is about $15^{\circ}$ grocers. They originated not in the days of SchulzeDelitzsch, when the position of independent retailers was yet undisputed, but after the emergence of large-scale retailing and consumer's co-operation in the I880's. There were at first some qualms about endangering the position of private whole-

2Sometimes called co-operative chain stores. The term is subject to misunderstanding, however, as it can apply either to a consumers' co-operative chain store, or to a group of independent stores associated with a purchasing co-operative, or to a retail outlet of a farmers' marketing co-operative. 
salers, but after several boycotts by manufacturers, the principle of group-purchasing was firmly established among retailers. Other groups of shopkeepers followed later and successfully organized trading co-operatives for textiles, footwear, hardware, stationery, and drugs.

Among artisans, where co-operation had begun at its very earliest stage, the expansion of purchasing associations has been more limited. This is largely due to the fact that in handicraft, the purchase of materials is a less important factor than

TABLE VI

Artisans' Purchasing Co-operatives, 1957

\begin{tabular}{|c|c|c|c|}
\hline Artisans' Group & $\begin{array}{l}\text { Number of } \\
\text { Co-operatives }\end{array}$ & $\begin{array}{l}\text { Number of } \\
\text { Members }\end{array}$ & $\begin{array}{l}\text { Annual Sales } \\
\text { (million DM) }\end{array}$ \\
\hline 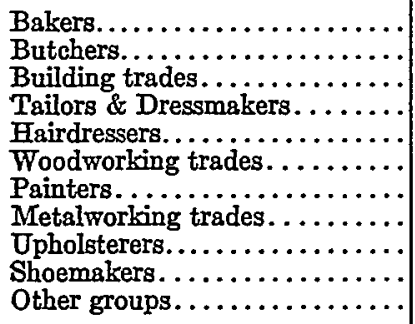 & $\begin{array}{r}243 \\
171 \\
29 \\
18 \\
15 \\
34 \\
37 \\
25 \\
18 \\
60 \\
11\end{array}$ & $\begin{array}{r}32,100 \\
22,000 \\
1,500 \\
1,700 \\
2,100 \\
2,000 \\
6,500 \\
3,700 \\
1,900 \\
6,200 \\
1,000\end{array}$ & $\begin{array}{r}635.0 \\
268.0 \\
55.6 \\
3.7 \\
10.0 \\
15.5 \\
35.6 \\
64.7 \\
18.0 \\
15.5 \\
14.2\end{array}$ \\
\hline 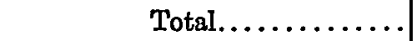 & 661 & 80,700 & 1135.8 \\
\hline
\end{tabular}

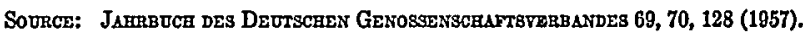

in retailing, and can, therefore, not yield such substantial savings. The great exception is baking. There are now 243 local bakers' purchasing co-operatives whose total sales volume exceeds that of all other artisans' co-operatives. (See table six.) Their membership figure represents more than half of the 55,500 bakers and confectioners in West Germany. In a bakery, flour is a crucial cost factor. Other requirements are also supplied by the co-operatives. In looking at the sales figures, one also has to take into account the sales volume of the specialized central wholesale agencies in the different branches-in the case of bakers, with sales of DM 203,000,000 in I957-which is not shown. At present, new plans are under discussion that bakers give up making all varieties of bread which they sell, but instead hand over part of their production to local co-operative bakeries which will supplement their individual baking.

The situation is similar with butchers, where also about half have joined cooperatives. They buy their meat, however, mostly through municipal slaughterhouses; co-operatives handle only their other requirements and do the marketing of butchers' by-products. Upholsterers and home decorators have developed an interesting pattern of co-operative showrooms, with a greater variety of materials than they could have in stock individually. Customers can make their selection there, so that artisans are in a position to compete with department stores, without a high 
investment in stocked materials. However, in many of the artisans' groups, shown in table six, co-operative members are only a minority of all artisans in the trade. This is partly explained by the fact that co-operatives have not been set up in all localities. In a few branches of handicraft, there is practically no co-operative purchasing, especially in those that have developed only recently, so that the figure of 80,700 members of co-operatives in all trade groups represents ro. 6 per cent of the 752,000 artisan firms in existence. It is, in fact, more difficult for artisans than for retailers to run a co-operative business. They are trained to be craftsmen more than businessmen, and are unaccustomed to the task of supervising the operations of a purchasing association. Medium-sized artisan firms have more frequently made use of co-operatives than the very small ones, partly because the contribution of required share capital can act as a barrier. It is still an open question whether members who place larger orders shall be given preferential treatment in prices. This may be a necessary concession to keep them in the group plan, but it has always been controversial, because the members are, after all, competitors in their own market.

Some artisans' co-operatives have been set up to perform a marketing service for their members, mainly for the sale of highly specialized products like jewelry, musical instruments, and sets of surgical instruments, which are made by a number of artisans in a division of labor. Others seek to obtain government and export orders as bulk contracts for distribution among their members.

All these types of co-operative enterprise have helped handicraft to adjust itself to the conditions of a competitive economy. This had been the most important aim of Schulze-Delitzsch. He had rejected not only government regulations to assist small producers, but also government aid and government supervision of cooperatives. The co-operatives have since adhered to this principle, even under a democratic government. Some branches of handicraft had to give way to factory production as a result of technological development. These could, of course, not be saved by co-operative efforts, but to others, this has been a decisive factor. The persistence of so many small bakeries, for example, which sell directly to the consumer, can largely be attributed to successful co-operation.

Small manufacturers have been far more hesitant to solve some of their problems co-operatively. Their weakness in the buying market is less apparent than with small retailers and artisans. What they are lacking, for example, is access to facilities for research and new technological development. To solve problems which cannot be tackled by small and medium-sized firms individually, they can establish a joint research institute. This has been done in Norway recently. To accomplish this, business leaders must be willing to co-operate and even to reveal some of their own technical progress to the others. Mutual distrust has often been stronger. Manufacturers have not yet produced much evidence of co-operation, but have worked more through manufacturers' associations, whose main function is to co-ordinate complaints and to influence government regulations. It may be that they have come 
to associate co-operatives so much with other groups in the economy, that they cannot think of themselves as co-operators. But it should be noted that there could be much scope for joint activity: small firms could establish co-operative export agencies, consultant services to advise on new techniques and plant layout, and electronic computing centers for the processing of data. Comparative cost analysis, standardization of goods, and a certain co-ordination of production could also be accomplished by such groups of firms. It may well be that we shall experience co-operative developments in these fields as the concentration of large-scale enterprise continues.

In transport, co-operatives have given very effective assistance to independent truck operators and shipowners. There are eighty co-operative associations in road and inland waterways transport, which secure the advantages of large firms for their members. They obtain freight orders, store goods in freight terminals, purchase requirements, finance members' operations, give credit for new equipment, and provide a repair service. They also negotiate with public authorities on behalf of their members. By this combination of services through their co-operatives, some 20,000 small transport firms have strengthened their competitive position and retained their independence.

In the vital field of credit, it has been possible in many cases, to overcome the limitations of small business by the functioning of co-operative credit banks. They serve artisans as well as retailers and small manufacturers, and provide an important link in the co-operative structure. They first had been established under the guidance of Schulze-Delitzsch, with two objectives in view. They function as credit unions by pooling members' savings and using them for credits to members when the need arises. Secondly, they supplement the credit volume which is thus available by bank loans from outside sources, for which the whole association gives a collective guarantee. The law provided unlimited liability of members at first and was later amended to permit limited liability. In this way, small firms were given access to credit sources which were, because of securities required by banks, not otherwise open to them. As these people's banks grew, they were able to provide more and more of the loans out of their own funds and those of co-operative central banks. In contrast to private banks, they give most of their credits to small debtors, but they have come to ask for much the same securities as other banks. In the years of extreme capital shortage following the war, artisans especially were in need of personal loans which could only be given on the basis of guarantee. Therefore, regional handicraft societies established regional guarantee associations which would help artisans get credit from people's banks or other banking institutions. They followed the example given by mutual guarantee associations in Switzerland, which have, however, been formed by small businessmen themselves over a period of decades and have received some government assistance.

People's banks in Germany have again accumulated funds and strengthened their position. Table seven shows their development since 1950 . There has been a considerable increase of deposits and loans outstanding. The people's banks had, like 
TABLE VII

People's Banks, I950-57

\begin{tabular}{c|c|c|c|c|c|c}
\hline \hline Year & $\begin{array}{c}\text { Number of } \\
\text { Local Banks }\end{array}$ & $\begin{array}{c}\text { Number of } \\
\text { Members } \\
\text { (thousands) }\end{array}$ & $\begin{array}{c}\text { Deposits } \\
\text { (million DM) }\end{array}$ & $\begin{array}{c}\text { Loans to } \\
\text { Members } \\
\text { (million DM) }\end{array}$ & $\begin{array}{c}\text { Balance } \\
\text { (million DM) }\end{array}$ & Per Bank \\
\hline $1950 \ldots \ldots \ldots \ldots$. & 680 & 553 & 869 & 947 & 1,255 & 1,845 \\
$1955 \ldots \ldots \ldots \ldots \ldots$ & 688 & 631 & 2,538 & 2,413 & 3,402 & 4,945 \\
$1956 \ldots \ldots \ldots \ldots \ldots$ & 692 & 659 & 2,907 & 2,677 & 3,870 & 5,608 \\
$1957 \ldots \ldots \ldots \ldots$ & 3,502 & 2,909 & 4,563 & 6,542 \\
\hline
\end{tabular}

SOURCE: JARRBUCB DEs DEUTSCBEN GenossenschartsVBraANDEs 36-42 (1957), and previous yearbooks.

many other co-operatives, survived dictatorship and war and developed new growth in recent years. A large share of the deposits is today contributed not by small independent people, but by civil servants and employees, while most of the loans go to artisans, retailers, and, to a smaller extent, manufacturers. The local people's banks are federated into regional banks, which, in turn, obtain further credits through the central co-operative bank. For auditing and advisory services, they have, together with the trading co-operatives, joined regional co-operative unions and the central co-operative federation. In addition, there are two national banks to help them with special credits, a central co-operative mortgage bank, and a cooperative savings bank for building purposes. A postwar development has been the establishment of forty-seven co-operative installment credit banks whose function is to take the burden of installment credits which member retailers and artisans extend to their customers. Thus, they enable them to compete with the favorable terms which large firms offer in their sales efforts.

While the whole comprehensive structure of co-operative enterprise described so far works to improve the bargaining position and efficiency of existing small firms, there is another type of association whose object is to start its members in business after due preparation. The young grocers' saving association, called Spara, collaborates with the Edeka purchasing co-operatives. The members are employees who pledge to save regularly and who take special courses to prepare themselves to become independent grocers. After three years of saving, they can obtain a personal credit from the Edeka Bank. This will be up to seven times the amount the saver has contributed, and at a rate of interest equal to that which was paid to him. The association will help in finding a suitable shop and in negotiating a lease, and the Edeka bookkeeping service will help with the records. The loan is then to be repaid in three years. Spara associations have been established by Dr. Paul König of the Edeka since I930, and since I950 alone, some 300 young grocers have been launched as independent retailers. They have come to know the ideas and the scope of self-help at an early stage and provide a new influx for purchasing cooperatives.

A similar method to promote independence with a training for self-responsibility has been adopted by bakers, butchers, and other artisans' associations. These work 
in close collaboration with people's banks, and even though these savings plans have only been in operation for a few years, there are already some 7,000 young artisans' savings accounts under this program. As the amount of capital required for the establishment of a new business has become a crucial barrier, it is to be expected that such co-operative plans to facilitate ease of entry will gain in importance. Some of these various types of co-operatives which have been set up in Germany, have also been developed in other countries at about the same time or have later been adopted there. Although there were contacts between co-operative pioneers, as between Hermann Schulze-Delitzsch and Luigi Luzzatti in Italy, the course of development has sometimes been different. Especially the role of the state has often varied.

Purchasing co-operatives of food retailers exist in many European countries. The principle of local associations with a central federation has, in the same way as in Germany, been adopted in Austria (Adeg organization), the Netherlands (Sperwer and Enkabe organizations), and Belgium (Cenko organization). In France, there are a number of local associations, especially in the East and North, but no regional or national trading federation. In Switzerland, Sweden, and Norway there are no local associations, but a number of regional purchasing co-operatives with a loose national federation. Denmark has regionals without a federation. In Finland, the retailers are direct members of a centralized national organization, Kesko, which is, in spite of a strong consumers' co-operative movement, the largest wholesaler in the country. ${ }^{3}$ There are also purchasing co-operatives for other sectors of retailing in some countries. Sometimes these purchasing associations have, as in Germany, adopted not the legal form of co-operative, but some form of joint stock corporation where retailers are the shareholders.

Co-operative people's banks that have been established in other countries are often built on a much stronger element of central control. The pattern of numerous local banks for small enterprise with their federal organizations, which is typical for the German people's banks, is-also found in Austria, Italy, and in the Frenchspeaking part of Canada. In France, Belgium, and the Netherlands, there are centralized people's banks which are semipublic, but France has also a substructure of local mutual guarantee associations and less numerous people's banks. A recent development of co-operative credit has taken place in Turkey, where a centralized people's bank serves the whole country in collaboration with local guarantee associations.

In some countries, the government has been called upon for providing only the legal status which co-operatives require for their functioning. In others, it has been active in promoting the establishment of co-operatives. In a number of countries, the government has, when it was decided to give some form of public assistance to small businessmen, directed funds through co-operative enterprise to increase the capacity for self-help and to develop self-responsibility among those concerned. This

${ }^{8}$ See Paul König, Selbsthilfe im Wettbewerb i2-I6 (I956). 
course of action may well be adopted as a policy in those countries which are now striving for economic development.

In any case, the voluntary effort of small businessmen is necessary as a basis. This has been lacking in some Mediterranean countries, with their traditional individualism, and in England, where it seems that small independent producers and retailers have just gone out of business when conditions have turned against them. Perhaps they did not think of forming co-operatives of their own because they felt strongly against the competition of consumers' co-operation, which, to them, had a socialist flavor. In other countries, where government aid has been an important factor in co-operative development, there has often been a lack of lasting self-help efforts. This can be avoided when public aid is only used as an initial assistance to stimulate voluntary co-operative action. In countries where self-help has shown its strongest development, co-operators have rejected state intervention. Co-operation will flourish best in freedom of enterprise.

Co-operatives have protected the independence of small businessmen against intrusion by stronger competitors by increasing the competitive strength of independent enterprise. They have made them a more vigorous partner in the competitive economy and have, above all, increased confidence in their ability to sustain their independence. 